\title{
Oggetti Spaesati, Unhomely Belongings Objects, Migrations and Cultural Apocalypses
}

\author{
ILARIA VANNI
}

UNIVERSITY OF TECHNOLOGY, SYDNEY

My husband also packed his organetto (button accordion). He learned to play it when he was a young shepherd in the hills of Conflenti. He and the other shepherds used to have to go into the hills at night to look after the livestock. During the day, while the animals grazed happily on the rich pasture they had nothing much to do. To fill the hours they taught themselves to play the accordion. Battista became a very talented musician and in Australia was often called upon to play at feste [festivals, parties] and family celebrations.

For the last twenty-five years our family has lived happily in the same house. My husband sadly died just over a year ago and so his barber kit and organetto have become very important not only to me but to the rest of my family ... These precious belongings will definitely be handed down to our grandchildren as loving mementos of a wonderful husband, father and grandfather. 
The story of the three lives of the organetto, first as a shepherd's instrument of choice in Italy, then as the instrument played at parties and celebrations in Australia and finally the memento of a beloved husband, is told by Rosina Benvenuto in a firstperson narrative about objects selected for their significance in the experience of migration from Italy to Australia. It can be read as a story of persistent cultural traditions; as the description of an heirloom; as nostalgia; as the biography and social life of an object, sketching its journey of migration from one place to another; or as an object whose story questions ideas of belonging, origin and authenticity. My argument is that diasporic objects such as this organetto and others to be mentioned in this article, are central to migration because they emplace and enact multiple geographies of 'home', including its opposite, 'the unhomely'.

I use 'unhomely' to translate the Italian word spaesato (feminine spaesata, plural spaesati and spaesate), which literally means 'without a village, without a country' and encompasses further meanings of having lost familiar relations to things and places, being in an unfamiliar environment, being or feeling lost, having lost one's bearings, being displaced, being confused, being out of place. Spaesato has its origin in paese, a complex word meaning literally village or country that also covers the concepts of home, homeland, hometown, and denotes the fundamental unit of belonging. ${ }^{2}$ In this sense the word is particularly relevant when thinking about the emotional geographies of migration. Francesco Ricatti has explored the idea of spaesamento in relation to the Italian diaspora in Australia in the postwar years, writing about spaesamento in terms of bewilderment as a migrant condition, and focusing in particular on physical illness and suffering. He notes that in addition to being displaced from their paesi, migrants are doubly displaced 'from the dreams and fantasies that had fostered and often determined the process of migration'. ${ }^{3}$ The noun relating to the adjective spaesato, spaesamento, has also being used as a translation of the German unheimlich and English unhomely and uncanny, generally translated in Italian as il perturbante (that which causes perturbation, disturbance). ${ }^{4}$

This article reflects on the uncanny as feeling and being spaesata or spaesato as a contribution to the debate of this special section on the spaces of uncanny perceptions, memories, narratives and identities of the Italian diaspora in 
Australasia. My reflection is guided by Ernesto De Martino (1908-1965), an anthropologist, philosopher, historian of religions and folklorist best known to Anglophone audiences for his study of tarantismo (the ecstatic healing cult centered on the bite of a spider, the taranta, practiced in southern Italy) titled The Land of Remorse, to date his only book translated into English. ${ }^{5}$ De Martino studied with Benedetto Croce, and critiqued the latter's idealist historicism in the light of his interpretation of phenomenology (Husserl in particular), Heideggerian existentialism and Gramsci's political theory, which led him to write the ethnographies of subaltern groups. ${ }^{6}$

De Martino in an anecdote in La Fine del Mondo ('the end of the world', posthumous edition 1977), describes lo spaesamento in relation to belonging to a village (paese, here symbolised by its bell tower, il campanile, from which the Italian word campanilismo, used to describe the affective and emotional attachment to one's hometown, originates). The anecdote is a micro-migration story, narrating the vicissitudes of a Calabrian shepherd who for the first time in his life leaves his native village in a car. The story is set at sunset. De Martino is driving along a lonely road in a remote area of Calabria, and he is lost. With some relief he comes across an old shepherd and asks for directions. The shepherd's explanation is confused, and De Martino asks him to go in the car to the right turn (there is talk of some compensation). The shepherd is diffident, and his reticence grows once the car drives off, until:

It became real anguish, because now, from the window he kept looking through, he had lost the familiar sight of the bell tower of Marcellinara, the landmark of his minuscule existential space. Because of the disappearance of that bell tower, the poor old man felt completely lost (spaesato): and he became agitated to the point to show the signs of desperation and terror, so that we decided to bring him back to where we had met him. On the way back he kept his head out of the window, anxiously surveying the horizon, to see the reappearance of the domestic bell tower: until, when he finally saw it again, his face relaxed, his old heart started to appease, as for the recovery of a lost homeland. ${ }^{7}$

De Martino uses this story to explain lo spaesamento in terms of loss of domesticity and domestic horizons. This loss of familiar signs leads to a progressive feeling of 
unhomeliness and panic, perceived as the loss of ability to read, speak and make sense of the world according to a common cultural blueprint. Lo spaesamento finally results in 'the shipwreck of intersubjective relations'. ${ }^{8}$ At stake is what De Martino calls le patrie culturali (the cultural homelands), that constellation of things, practices, words, habits that are produced and, in turn, produce a common lifeworld. When the links between things, practices and words within these constellations turn loose, we no longer have the ability to operate in the world. 'The modern world' De Martino writes, 'has become particularly sensitive to the problems raised by the different patrie culturali, and their relationships, exactly because we live in an era of migrations, encounters, comparisons.'9

Later in this article I will return to De Martino's analysis of cultural apocalypses as a parallel thinking to the uncanny despite the fact that De Martino is generally not included in the 'canonization of the uncanny'.10 I introduce a different perspective to the uncanny canon, and, in conversation with other articles in this issue, to invite the reader to consider what De Martino terms la crisi della presenza (crisis of presence) in relation to some of the multiple meanings of the uncanny.

-BELONGINGS, THE EXHIBITION

The story of the three lives of the organetto, and its photograph, are part of Belongings: Post-WW2 Migration Memories and Journeys, an ongoing online exhibition curated through the NSW Migration Heritage Centre (MHC), Powerhouse Museum, and supported by the Community Relations Commission for a Multicultural NSW. Belongings was initiated by John Petersen, MHC's manager, who drew inspiration from The National Quilt Register, an online project that collects stories and photographs connected to quilts. The Quilt Register was developed by the Pioneer Women's Hut, a museum in Tumbarumba, in southern New South Wales. Heritage consultants Meredith Walker and Kylie Winkworth, community historian Mary Ann Hamilton and community heritage officer Linda Nellor from the Italian organisation Co.As.It. contributed to the conceptual development of Belongings. ${ }^{11}$ Andrea Fernandes, the exhibition's curator and coordinator, explains that through the online exhibition 'Personal, first-hand experiences of post-World War II migrants are recorded through their special memorabilia, or belongings, in 
English. We meet people in their homes-the nation's museums-and they share with us the stories behind their mementos.'12

Belongings' online collection includes oral histories and digital images of objects chosen by people from forty-four different cultural backgrounds who arrived in Australia between 1946 and 1974. The objects selected range from a beach pebble to clothes, linen, postcards, musical instruments and tools. These objects remain with their owners, in the belief that material culture better retains its meaning when left in its context, in accordance with the NSW movable heritage policy directive. ${ }^{13}$ Belongings are photographed in situ, inscribed with the life history narratives of their owners who are interviewed in their homes and given a digital life on the exhibition website. ${ }^{14}$

Belongings includes objects from twenty-nine Italian participants who were selected in partnership with local community and cultural organisations. Despite the effort to be inclusive, the people represented in the exhibition tend to be largely women from rural backgrounds in southern Italy. There are some notable exceptions: urban migrants; people who migrated not for economic reasons, but because they were stateless after World War II; a few people from rural northern Italy. While in general there is no connection between participants, one significant group of people who left the village of San Ferdinando in Calabria to move to Leeton in the Riverina region in New South Wales as part of a chain migration, stands out. Not surprisingly, given the gender unbalance $(73$ per cent of participants are women), the social and historical moment of their migration, and the reproduction of existing hegemonic gender relations, cultural, and spatial practices once in Australia, about 60 per cent of the objects presented as mementos are domestic objects.

The naturalisation of women as belonging to the private sphere of migration has been recently analysed and contested as a key factor in creating gender inequalities by anthropologist Loretta Baldassar and historian Donna Gabaccia. ${ }^{15}$ The authors instead propose to engage with the narratives of affect and intimacies that are left out from discussions on mobility, migration, transnationalism and nation building. Baldassar and Gabaccia move Benedict Anderson's concept of imagined community away from the public sphere of print capitalism to focus on 'the deeply felt emotional solidarities that more resemble those of domestic and 
familial life' to redress this oversight and consider the symbolic and affective spaces where (trans)national identities are formed.16 Belongings, with its focus on the materiality of the everyday, also engages with the narratives of intimacy, with 'the idiosyncratic, and deeply felt practices of individuals [that] become cultural expressions of national solidarity'. ${ }^{17}$

The collection is framed in what James Clifford called 'the salvage paradigm', the desire to rescue authentic cultural traditions from historical becoming that informed much twentieth-century ethnography and collecting practices and continues, often in the form of the digital repository, in this century. ${ }^{18}$ Objects and narratives, we learn from the website, were recorded to save the memories and histories of an increasingly elderly demographic in such a way that would be meaningful to future generations and so that these memories could be included in the Australian nation multicultural project, recognising the culturally diverse heritage of NSW people. ${ }^{19}$ Belongings, as an online exhibition, has therefore the evident pedagogical vision to reshape individual, fragmented life stories into a collective memory of Australia multicultural becoming.

\section{—OBJECTS IN THEIR PLACE}

My focus in this article, however, is not on the historical, methodological and theoretical underpinnings of Belongings as an online exhibition. Other researchers have written about the exhibition from multiple disciplinary points of view. ${ }^{20} \mathrm{My}$ interest is not in museography per se, but in Belongings as a rich, layered and crucial source to understand objects in the context of post-World War II Italian migration. In all the stories collected on the website objects play a central role not simply as devices to trigger memories, or as nostalgia, but as building blocks of migrant biographies in Australia. For instance, Teresa Iannelli, who left the Calabrian village of San Ferdinando to migrate to Leeton in rural New South Wales, explains how simple cups recreate a whole domestic landscape, including familiar relations and class connotations:

One of the belongings I have is a café latte cup. I remember I would have coffee and milk every morning and Mum would use these café latte cups all the time. Mum had a lot of beautiful things because my father's family were well off, so Mum would use these beautiful things every day. The 
teapot with the sugar bowl was also my mother's. I don't know how many years she had them but we used them often and I asked my sister for them. I love it and it reminds me of family breakfasts with my brother and sisters and because I was the youngest, Mum would always be there to spoil me. These belongings reminded me of my mother and are very special to me and I'm very glad I had them with me. ${ }^{21}$

I am interested in thinking about the role of objects in creating geographies of home and mediating from essere spaesati, to be unhomely, to sentirsi a casa, to feel at home. What happens when objects are moved from their original home, across borders, and are relocated in another country: do they lose their homeliness and do they become spaesati, unhomely? If it is true, as the NSW movable heritage policy rather poetically states, that one must leave 'objects in their place', I ask: what is their place?

Take the organetto in the story at the beginning of this article. It started its life with shepherds, as their pastime in quiet moments. Then it followed its owner to Australia, where it became the life of the party. Finally, it survived its owner as a keepsake, a repository of memories for present and future generations. Is its place pastoral Italy? Parties in post-war Australia? Its current physical home? Its digital home? Is it, perhaps, out of place?

More questions: what happens when objects travel? What is the place of migrant objects? Are they objects out of place, oggetti spaesati, unhomely objects? When they are relocated from what was once 'their place' to a new location, do they instantly regenerate familiar and homely spaces? What kind of affective space is produced by migrant objects?

\section{- HOMES: THE NATION'S MUSEUMS}

In a paper on Belongings, Andrea Fernandes establishes the importance of domestic environments in the making of a collective, national memory. 'If we think about it', she writes, 'our homes are the nation's museums. Our belongings are on the kitchen stove, under the bed, at the back of the shed.'22 The importance of home in the diaspora, as a physical, geographical, conceptual and affective understanding, has been investigated by Loretta Baldassar in her groundbreaking ethnography with Italian Australians between Perth and San Fior in the Veneto region of Italy. Here 
Baldassar makes the argument that home is not a crystallised locality in another place and another time, and that home, 'going back home', and the traffic of affects, objects, images and people between the two places are constitutive of migration. ${ }^{23}$

Home as the site of ethnographical fieldwork, the object of anthropological inquiry, the location of studies of material culture and of consumption, and the privileged locus to observe social transformation has produced a considerable body of literature, as discussed by Daniel Miller in the introduction to his edited volume Home Possessions. ${ }^{24}$ Alison Blunt and Robyn Dowling navigate the multiple senses, understandings and representations of home as a key idea in contemporary geography, including 'the transnational home', as a site of migrant memory and homemaking practices and domestic aesthetics. ${ }^{25}$ The relationship of objects to migration and the making and decorating of 'home' in the Australian context has been also explored recently in relation to issues of identity by Michelle Barrett. ${ }^{26}$

Rita Wilson, writing about Italian Australian women's fiction, observes that 'home/land', as a site of loss or desire, as a remembered and imagined place, and as 'a complex intersection of language, history and environment' plays a central role in the development of migrant identities. Wilson acknowledges the intellectual position of some literary scholars who identify three stages in the development of these identities. According to Gustavo Pérez Firmat, for instance, at first migrants try to recreate substitutes for the lost home; in the second stage migrants feel estranged from their new location; and in the third migrants establish new relations with their new place. ${ }^{27}$ Against this teleological drive, Sara Ahmed, Claudia Castañeda, AnneMarie Fortier and Mimi Sheller propose an idea of migration as a continuum of experiences. They question and trouble the idea of home as something pre-existing migration, as having 'an essential meaning in advance of its making', proposing instead a focus on 'homing' as a feature of the interdependent relation between home and migration. ${ }^{28}$ They write:

'Homing' entails processes of home-building, whether 'at home' or in migration. Making home is about the (re)creation of what Eva Hoffman would call 'soils of significance', in which the affective qualities of home, and the work of memory in their making cannot be divorced from the more concrete materialities of rooms, objects, rituals, borders and forms of transport that are bound up in so many processes of uprooting and 
regrounding. Homing, then, depends on the reclaiming and reprocessing of

habits, objects, names and histories that have been uprooted-in migration, displacement or colonization. ${ }^{29}$

In thinking about home and the unhomely in relation to migration, I find it productive to draw upon Ahmed, Castañeda, Fortier and Sheller's notion of uprooting/regrounding as 'a plurality of experiences, histories and constituencies, and the workings of institutional structures' against neat disjunctures of 'home' and 'migration'.30 The authors consider uprootings and regroundings as 'specific processes, modes and materialities'31 to depart from ideas of location in transnational theory as the distinct national formations of here and there and to blur this distinction to ask questions such as "Where or what is "there"? Is it necessarily not "here"? How long is "there" a significant site of connection? And for whom? How far away is "there"?'32

Home is not, according to the authors, the opposite of mobility, but rather it includes the idea of movement, a continuous production and reproduction of domestic space through affective labour. ${ }^{33}$ This theme is present in many of the narratives in Belongings: home is reproduced through everyday gendered gestures and tools, through Italian women's unwaged domestic labour that produces not only material results, but also ecologies of home, made of an affective atmosphere generated by sensory evocations, repetitions of gestures, and memories. Home, in these narratives, is made through care, reproductive and domestic work, often (though not always) in addition to factory or agricultural labour. Domenica Scarcella for instance worked at home in her first period in Australia: 'I didn't work for the first ten years. I waited until all three of our children, Lilly, Susie and Eugenio, were born. My first job was as a dressmaker at Sasha Boutique in Burwood. I worked there for seventeen years.' 34 Similarly Carmela Pasquetti recalls: 'I did not go out to work, I was expected to look after the house and help my parents. I was expecting Australia to be something nice and be full of beautiful rich things, but it was not like that at all. I had to work very hard as a young person.'35

Carmela recounts also how tomato sauce, the tools and their names and the procedures to make it, translated Italian domestic habits into an Australian one:

One of the kitchen things we packed was a setaccio, an aluminum tomato sieve which is used to make pasta sauce. We would boil the ripe tomatoes 
and let them cool a little, then squeeze the tomatoes through the sieve. The skin and seeds are left on top and the puree is able to pass through the holes and is caught in a bowl underneath. In Italy, and later in Australia, we would do this every time we would have pasta sauce which was a lot. In the summer, when there were a lot of tomatoes we would do a big batch, pour it into bottles and preserve it for the winter months. ${ }^{36}$

By linking everyday objects to narratives of migration, Belongings is rich in examples of uprootings/regroundings and homing as affective qualities of homes modulated by rituals, habits, objects. The objects in Belongings are, with a few exceptions, examples of what Joseph Sciorra calls the 'vernacular cultural production' of Italian migrants (in his case in the United States of America). ${ }^{37}$ The objects in Belongings are located in a domestic and domesticated horizon, and they are part of everyday aesthetics. Some objects are of evident utilitarian value such as cooking tools: 'In the trunks I had packed saucepans, dinner sets, everyday plates and cups, a cutlery set, all sets for twelve people', ${ }^{38}$ remembers Concetta Cosentino. Others are also of aesthetic value such as the hand-embroidered linen in Raffaella Porcu's memories:

I [also] brought the handmade sheet sets, the ones with the pink embroidery I made while I was still in Sardinia. I would mark the design of the edging first, then stitch the coloured material into the pattern and then I would iron it and then start the special stitches called punti rodi, punti peno and punti delba. ${ }^{39}$

Sciorra reminds us of the importance of this vernacular aesthetic not simply as personal appreciation of beauty, but also in terms of the social construction of taste which both connects and differentiates individuals in recognising the aesthetic value of an object. In this sense objects perform the Italian ritual of bella figura: 'an adherence to proper comportment and the aesthetic dimension of such performance.'40 Some things, for instance, would be used to mark special occasions, or to impress a guest and at the same to show respect and recognition of the social status of the guest, as Teresa Pirrottina, who migrated as part the chain migration form San Ferdinando to Leeton, explains: 'These special things were not used everyday; they were used for special occasions or when the doctor would come around.'41 
Belongings foregrounds the vernacular is further through the objects being photographed as snapshots, in the home of their owners. There is no attempt to render these objects as museum items professionally photographed in a studio. In the making of the exhibition the MHC partnered with cultural and community organisations, selecting the interviewer based on oral history skills, while the importance of photography skills was marginal. ${ }^{42}$ The result is an uneven photographic record: objects are photographed in situ, they are 'objects in their place'. Sometimes they are held by their owners. Sometimes they sit quite precariously (especially when they are fragile) on their own. Sometimes the background is just visible; sometimes the photograph is so close cropped that the object seems to spill out of the frame. The everydayness and homeliness of the visual is echoed in the choice of editing with a light hand the oral histories collected during the interviews, so that the narratives are 'written with an accent'43 and Italian or Italian dialects words often interrupt the English: lo sculla pasta, il corredo, il setaccio, le comari ...

\section{—UNHOMELY}

Most migrant material items in the exhibition Belongings fit the sphere of domesticity: they are objects used to 'make home', or one could say they are homely, or appaesati (the contrary of speasati). Others, generally chosen by men, are associated with work (according to the division of public/private spheres that saw men as working outside and women working inside the home, which has been contested by Baldassar and Gabaccia), ${ }^{44}$ and some are souvenirs of the journey from Italy to Australia. All of them are held in homes. ${ }^{45} \mathrm{My}$ argument is that the sense of belonging-and of being familiar with-generally attributed to a specific location, such as the space defined by the bell tower as in the story of the shepherd and il campanile della Marcellinara, is translated in the experience of migration to an imagined and experienced geography put into place through objects and practices connected with these these objects. The geography of home recreated by these objects is by no means a faithful translation, copy or substitution of the "home back home': objects are emplaced in new cultural landscapes. Teresa Restifa narrates of her arrival in Sydney after the devastation of the Messina earthquake in 1968. Here, space resists domestication through known and used objects: 
When we arrived in Sydney, I got sight of the Opera House that was being built at Circular Quay. The Harbour Bridge, I already knew about as my uncles used to send me postcards featuring the Bridge. It all looked pleasant but strangely quiet. We were used to Palermo [Sicily], a bustling city. We really didn't like it at first. At the end of our first day we went to see our unit that our uncles had organised for us. The flat was owned by a cousin and he let us have it for as long as we needed it. They filled it with furniture, linen, everything for the kitchen. We brought everything that we could salvage from the earthquake including an Egyptian cotton bedcover. My grandmother's sewing machine was rescued; I've still got it now, it is about ninety years old. It still works really well ... The apartment was fine but it had laminex furniture and we had had very beautiful stuff [in Italy], we had had a beautiful house full of antiques. Now we had laminex. We appreciated what had been done for us but it was a shock.46

The evocation of laminex furniture caught in between the homely and its opposite the unhomely creates an uncanny domestic geography and contributes to the feeling of spaesamento. The character of homeliness takes new connotations when we consider it in the context of postwar Australian migration policies, in particular the White Australia Policy, and the assimilation policy, which expected non-British migrants to leave their customs and cultural practices behind and embrace the Australian way. ${ }^{47}$ In the process of becoming Australian, cultural traditions also migrated from the outside and public spaces to the private spaces of migrants' homes, only to come out in the plain sight of multicultural Australian policies half a century later as digital artefacts in an online exhibition. In this sense, homeliness, unhomeliness and their location was predicated upon the ethnicised and gendered spatial relations dictated by political powers through a succession of policies, including assimilation and integration. ${ }^{48}$

\section{-CRISIS OF PRESENCE}

Ambiguity around the meaning of 'the unhomely', and the understanding of 'the unhomely' as a process, also surfaces in the experiences of post-World War II Italian migration to Australia as documented by the stories in Belongings. I am particularly interested in the idea of specific processes, modes and materialities, to think about 
the uncanny as spaesamento as a tonality and as a process that marks post-World War II migration experiences. In my reading I bring together two conceptual threads: Sara Ahmed, Claudia Castañeda, Anne-Marie Fortier and Mimi Sheller's uprooting/regrounding as a continuous process discussed earlier, and Ernesto De Martino's work on cultural apocalypses and crisi della presenza, meant as the loosening of things from familiar contexts and linguistic networks and their subsequent loss of familiarity and operability and loss or excess-and therefore ambiguity - of meaning.49 One of the central themes in De Martino's work is the crisi della presenza (the crisis of presence), which in the first half of the 1960s he explored as part of the theme of 'the end of the world' using a comparative approach. In particular, he collaborated with the neuropsychiatrist Bruno Callieri on the psychopathological aspects of apocalypses, approaching it from an interdisciplinary angle comprising psychoanalysis, art, literature, religion, ethnology, and philosophy. ${ }^{50}$ In addition to psychoanalytic literature, referred to in his discussion of the 'psychopathological apocalypses', ${ }^{51}$ De Martino used a selection of twentieth-century literary texts including Jean Paul Sartre's Nausea, Alberto Moravia's La Noia, Hugo von Hoffmannsthal's The Lord Chandos Letter, and Marcel Proust's Remembrance of Things Past to isolate and then illustrate examples of the emergence of what he termed le apocalissi culturali (cultural apocalypses) in a modern and bourgeois context.52 Le apocalissi culturali, according to De Martino, are historically determined and culturally situated. They do not articulate an end of the human world as such, but rather the end of a historical, cultural or political period or of a specific lifeworld. Apocalypses brought about by specific circumstances, or traversing historical periods, can be tonalities, moods to which individuals become attuned. Finally, cultural apocalypses provide the possibility of resolution of crisis and renewal. We read:

Cultural apocalypses, in their general connotation, are manifestations of cultural life that involve, in the context of a given culture and historical moment, the theme of the end of the current world, regardless of the way in which this end is actually lived or represented. In this more general connotation the theme is not necessarily linked with religious life as traditionally understood, but it can surface-such as in the case of the diverse modern and contemporary apocalypses of the bourgeois society- 
in the secular sphere of the arts, literature, philosophy, customs: it does not necessarily entail the end of the worldly character of human existence, but it can also take on the social and political traits of the end of a certain historical world and the coming of a better one, such as in marxist apocalypses: it is not necessarily explicit in the consciousness of the historical actors involved in these apocalypses, but it can become more or less explicitly manifest in the actors' Stimmung, in their behaviour, in the direction and affective tone of their thoughts; and finally a cultural apocalypse does not refer necessarily to collective movements, to overall tendencies of an epoch or of a society, but it can concern in a particular way a singular historical actor, who within the frame of certain environmental circumstances, opens up or renews a particular cultural sensibility to the end of the world. ${ }^{53}$

Migration, as uprooting and regrounding, can be read as one such moment. Migration is marked by what De Martino calls crisi della presenza (crisis of presence). La crisi della presenza can be explained as the loss of one's historical belonging and historical horizon, and of the consequent loss of intersubjective valorisation of people and objects (l'energia della valorizzazione della vita), which De Martino sees as the ability to operate, generate, communicate and share communal cultural values able to transcend the bare here and now of becoming. 54 Objects 'escape their frame',55 they become separated from their homely, familiar, domesticated background and from the network of latent memories, everyday gestures and usage, habitual words and idioms that makes it possible for things to function in the world, without the need of conscious thinking and translation.

This network is the result of everyone's cultural and historical biography, and constitutes the cultural blueprint that informs the way we act in the world (la patria culturale dell'agire). Once the network of relations between things, their usage and their meaning is broken, familiar objects lose their obviousness and become speasati. This is described by De Martino as:

a change in the operative domestic background that makes it possible to perform normally, according to purposes that have a shared meaning and are culturally integrated. To perform normally implies a homely (appaesato) background of relations that are admittedly obvious, and that, 
because of their obviousness, do not emerge in the actual consciousness ... This homeland of action (la patria dell'agire), this solid ground and certain horizon, even if immersed in the opacity of routine or in the obscurity of the unconscious, contains the treasure troves of implicit relations, of human beings' dramatic efforts to make 'home' and domesticate, of vast repositories of buried memories, which everyone accumulates according to her or his social and cultural-historical biography. ${ }^{56}$

This loss of the cultural blueprint and of the background of familiar relations between places, objects and words is evident in the story of Franca Arena, who migrated to Australia as a young single woman from an urban and educated background and who went on to become the first non-Anglo-Australian woman in an Australian parliament:

The trip was about four weeks. I arrived on 1 May 1959 in Melbourne, where the people with no relatives or anybody landed. The confusion and distress; I can hardly think back without getting a panic attack. It was so difficult and then we're put on this train that went on and on. Where are we going? Nobody was around on the train to tell us anything. I think we were on the train for eight hours. You know I love Australia but our countryside is not the most attractive in the world! It all looked the same, eucalyptus after eucalyptus! And then we're put on this train ... We were sent to Bonegilla migrant camp where people waited for a job. It was night when we arrived [and] I had to help to interpret to say, 'You go to hut number one.' Because I was an assistant I was given a hut of my own which was very good but also quite dangerous. There were a lot of very lonely, single men and I was scared. There was a wardrobe and when I went to bed I put it against the front door because you could hardly lock [it]. I remember going to bed crying and praying. I'm not incredibly religious, but I really prayed for God to help me. It was a traumatic time not knowing what would happen. We went to the dining room and the food was awful. I think it was lamb but we were not used to that terrible smell. Peas were as hard as bullets! Fortunately, speaking a bit of English, I was able to communicate to get milk for the children. I could see the anxiety on the faces of some families. I hated Bonegilla, it was a horrible place. I was a city 
girl from Genoa in a beautiful street with beautiful buildings. [Did] I come to Australia to go in a rural, decrepit area? I just couldn't stand it. They said I was going to stay and work as an assistant interpreter but I insisted in going to Sydney. They said I can, but I've got to pay for my own trip. Fortunately I had a bit of money and took the train to Sydney. ${ }^{57}$

Arena arrives in an unhomely geography of things that should be common but that take an estranged character: the smell and texture of food, the bedroom in the hostel that is both a refuge and a threat, the sameness of the landscape. Teresa Pirrottina illustrates the surging of the spaesamento, here located in a strange landscape supposed to be her new home, which together with the English language, 'meant nothing':

We were all excited about the train trip, but when we arrived in Leeton everything turned around. It wasn't what we were expecting ... It was mainly bush and no houses around. We were disappointed when we got off at the railway station [but] it was nice to see all our friends coming to meet us. My cousins tried to do the best for us. They blew up balloons and had written a 'Welcome Home' sign but it didn't mean anything to us. ${ }^{58}$ Another woman in Leeton, Rosina Rombola, connects material belongings and linguistic belonging: 'Everyone who came at that time didn't have much, like we didn't have much in Italy, but I had my language and I could understand, but here in Australia I could not understand anything.'59 Further south at Bonegilla, which opened in 1947 and was the first migrant camp to process post-World War II migrants, Edda Marcuzzi had nothing. Of the ten years spent in the camp she declares: 'If I start to remember, really remember, I cry.' 60

Once objects escape their domestication, losing their homeliness (appaesamento), as a result of personal or historical changes such as migration, they become unhomely objects, oggetti spaesati.61 This uncanny state (lo spaesamento) is marked by a crack in intersubjective communication, as objects either lose meaning and are subject to a 'semantic deficit', or acquire too much meaning, undergoing a 'semantic excess'.62 In the case of a semantic deficit objects become detached from the web of homely relations that makes their meaning obvious and that gives objects their 'secret warmth': objects become rigid, mineralised, or they wilt and collapse. In the case of semantic excess objects become charged with an opaque and suspicious 
allusiveness, which makes their meaning indeterminate or exceeding usual meanings. ${ }^{63}$ In both cases objects lose their familiar and obvious positions and functions and become unfamiliar. Gina Bortolin-Papa describes one of such objects, a healing scarf:

My mother used it on all her children to cure all sorts of ailments. For example, in my case, I suffered from a lot of earaches and sore throats. But she also used it for headaches as well as all general aches and pains. At one time it had some sort of hair woven through it but now, as you can see it is almost threadbare. It's probably about eighty years old now. I plan to tell my grandchildren all the stories my mother would tell me when she was comforting me with this healing scarf. 64

The same ambiguity of meaning, the oscillation and process between the ordinary homeliness of an object and its opposite is found in cultural apocalypses. The ambiguity in this case is between crisis, and the possibility of renewal, so that cultural apocalypses also describe the conditions to escape from the existing circumstances. ${ }^{65}$ Cultural apocalypses provide also deliverance from the loss of historical belonging showing the possibility of a renewed operability and domestication of the world. This ambivalence is noted also by Paolo Virno in his interpretation of cultural apocalypses as the ritual counterpart of the 'state of exception'. Virno recognises the uncanny at the core of cultural apocalypses in the ambivalence between crisis and the possibility of its resolution, and as '[o]scillation between something familiar that becomes uncanny, and something uncanny that returns to emanate familiarity.' 66

\section{-UN RICHIAMO DUNQUE ALLE COSE STESSE}

With Virno, I read the uncanny at the core of cultural apocalypses as a continuous process, an oscillation between an uprooting that produces uno spaesamento and a regrounding that brings back familiarity. In the context of migration as uprooting objects sustain a process of loss of their domestic placement and usage; of their relation with words, leaving behind their original name and acquiring a new one; of the web of latent memories that inscribes them in the flow of everyday ecologies. They become unhomely. If we consider migration also as regrounding, objects offer the possibility of translating the everyday into a new cultural grammar, and of re- 
establishing connections between latent cultural memories, language, usage. Objects become domestic, homely, again. 67

The process of regrounding, and the translation into a new cultural grammar, imply a gendering of objects according to an existing cultural blueprint. Domestic objects are restored to their operability and significance through unwaged domestic labour. Through usage, objects recover their everyday obviousness and create new ecologies of meaning, social relations, and new sensoria. Things assist regrounding by reproducing familiar domestic landscapes, enabling habits and translating memories and pasts into the present.

The ladies from the neighbourhood came to help me pack. The old ones would say, 'They don't have this in Australia so take this with you.' I packed three trunks plus suitcases to bring with us. I tried to get as much in them as possible when I came to Australia. I packed our clothes, saucepans, glasses, cups, the sculla pasta (colander). The zuppa (soup) bowls [once] were a set of six. I have only two left now but I used them at breakfast time every morning. I would put bread in the bowl, soak the bread with hot milk and a little bit of coffee and sugar. This was the children's breakfast. The word on the front 'Ricordo' means 'Remember' ... The wooden weaving frame I first used for weaving but when it got old I used it to make biscuits and macaroni pasta. The biscuits like nacatoli were cut into strips and then wrapped around the frame to make a pattern and then slipped off and fried. The strings inside the frame would give a pattern to the strips of pasta to make patterned macaroni.68

I brought three trunks and three suitcases when I came to Australia. I also brought a box with a seventy-two-piece [dinner set] that my sister gave to me as a wedding present. In the trunks, there were a lot of my glory box things - my dresses and things for the house. There were coffee cups and a tea set that my mother gave me and silver cutlery. I also brought out a lot of embroidery things. ${ }^{69}$

My mother packed as many of our belongings as she could and included special things that she had been keeping for our corredo (glory boxes), such as a new cutlery set, hand-embroidered sheets, towels and 
tablecloths. She also brought my embroidery loom that she had had made for me in 1956 when I was eight years old. ${ }^{70}$

I still use the coffee grinder I brought over from Italy many years ago. The smell is wonderful. Although I don't use my godmother's tablecloth much now, I used it a lot over the years. It is very sentimental to me now. It reminds me of my godmother and it is still beautiful. ${ }^{71}$

In the face of the 'disease of objects' that leads to a loss of familiarity, and of the relations between things and words, signifiers and signified, De Martino suggests un richiamo alle cose stesse, a 'retrieval of the things themselves', a return to the immediacy of everyday life. ${ }^{72}$ And it is through the same 'retrieval of the things themselves' that, as the stories collected in Belongings show, the cultural blueprint made of things, practices, words, sensations and affects is restored to its operability and lo spaesamento (the unhomely) fades into a new sense of home.

Ilaria Vanni is the head of the Cultural Studies Academic Group at the University of Technology, Sydney.

\footnotetext{
-NOTES

${ }^{1}$ Rosina Benvenuto, 'Rosina Benvenuto's Migration Memories', in Andrea Fernandes (ed.), Belongings:

Post WW2 Migration Memories and Journeys, interview by Linda Nellor, Co.As.It,

< http://www.migrationheritage.nsw.gov.au/exhibition/belongings/benvenuto/>.

2 Loretta Baldassar writes eloquently on Italian migrants' multilayered process of identification with

place as region and village or town in her book Visits Home: Migration Experiences between Italy and Australia, Melbourne University Press, Melbourne, 2001, p. 75.

3 Francesco Ricatti, Embodying Migrants: Italians in Postwar Australia, Peter Lang, Bern, 2011, p. 223.

4 Graziella Berto, Freud, Heidegger: Lo spaesamento, Bompiani, Milano, 1999. See also Sigmund Freud,

Saggi sull'arte, la letteratura e il linguaggio, vol. 1, Bollati Boringhieri, Torino, 1969. The essay known in English as 'The Uncanny' was first published in Italian in a translation by Celso Balducci as 'Il Perturbante', in Imago, no. 5, 1919.

5 See Ernesto de Martino, 'Apocalissi Culturali e Apocalissi Psicopatologiche', Nuovi Argomenti, vol. 6971, Luglio-Dicembre 1964, pp. 105-41; Ernesto de Martino, La Fine del Mondo: Contributo all'Analisi delle Apocalissi Culturali, Einaudi, Torino, (1977) 2002, Furore. Simbolo: Valore, Feltrinelli, Milano,
} 
2002; Ernesto de Martino, The Land of Remorse: A Study of Southern Italian Tarantism, trans. D.L. Zinn, intro. Vincent Crapanzano, Free Association Books, London, 2005. De Martino, The Land of Remorse. 6 Ernesto De Martino, Naturalismo e Storicismo nell'Etnologia, Laterza, Bari, 1941; 'Intorno a una storia del mondo popolare subalterno', Società, no. 5, 1949, pp. 411-35; 'I1 folklore progressivo' L'Unita, 28 June 1951; Sud e Magia, Feltrinelli, Milano (1959) 2002; Il Mondo Magico. Prolegomeni a una Storia del Magismo, Bollati Boringhieri, Torino (1973) 2003. See also George R. Saunders, '"Critical Ethnocentrism" and the Ethnology of Ernesto De Martino', American Anthropologist, vol. 25, no. 4, 1993, pp. 875-93.

7 De Martino, La Fine del Mondo, p. 480.

8 Ibid., p.479.

9 Ibid., La Fine del Mondo, p. 478. For a discussion of cultural apocalypses see also Paolo Virno, 'NaturalHistorical Diagrams: The New Global Movement and the Biological Invariant', Cosmos \& History, vol. 5, no. 1, 2009, pp. 92-104.

${ }^{10}$ For an in depth analysis of different readings and traditions of the uncanny and its canonisation see Anneleen Masschelein, The Unconcept: The Freudian Uncanny in Late-Twentieth-Century Theory, SUNY Press, Albany, 2011, in particular pp. 125-53. Critical discussions on De Martino and the uncanny appear in relation to the text The Land of Remorse in music therapy: Adriano Primadei, and Simona Nirensztein, 'Tarantism in Music Therapy: A Dialogue between Traditional Music and Psychic Suffering'. Keynote: 7th European Music Therapy Congress, Eindhoven, Netherlands, 2007, <http://www.shirmusictherapy.org/Shir/On_Tarantism.html>. The Italian psychiatrist Mauro Maldonato specifically links De Martino' s work on the theme of apocalypses to Freud's essay on the uncanny (il perturbante in Italian): Mauro Maldonato, 'Delle cose che non hanno volto', in Dell'Apocalisse. Antropologia e Psicopatologia di Ernesto De Martino, eds Bruna Baldacconi and Pierangela di Lucchio, Alfredo Guida Editore, Napoli, 2005, pp. 85-115.

11 Andrea Fernandes, 'Belongings: Post-WW2 Migration Memories and Journeys', paper presented at Moving Cultures, Shifting Identities: A Conference about Migration, Connection, Heritage and Cultural Memory, Flinders University, Adelaide, December 2007,

<http://www.migrationheritage.nsw.gov.au/belongings-home/about-belongings/belongings-paper/>. See also the exhibition website, <www.belongings.com.au> and for the National Quilt Register, $<$ http://www.collectionsaustralia.net/nqr/index.php>.

12 Fernandes.

${ }^{13}$ NSW Heritage Office, Objects in their Place. An Introduction to Movable Heritage, <http://www.environment.nsw.gov.au/resources/heritagebranch/heritage/objectsinplace.pdf>. $14<$ http://www.migrationheritage.nsw.gov.au/belongings-home/>. For the methodological use of objects in oral histories see Janis Wilton, 'Telling Objects: Material Culture and Memory in Oral History Interviews', The Oral History Association of Australia Journal, no. 30, 2008, pp. 41-9, 
<http://search.informit.com.au.ezproxy.lib.uts.edu.audocumentSummary;dn=107817039504100;res=I ELIND>.

15 Loretta Baldassar and Donna Gabaccia, Intimacy and Italian migration: Gender and Domestic Lives in a Mobile World, Fordham University Press, New York, 2011.

16 Ibid., p. 3. See also Benedict Anderson, Imagined Communities, Verso, London and New York, 1983.

17 Baldassar and Gabaccia, p. 3.

18 James Clifford, 'The Others: Beyond the Salvage Paradigm', Third Text, vol. 3, no. 6, 1989, pp.73-7.

19 'Belongings Guide: How to Record your Life Story and Special Mementos',

<http://www.migrationheritage.nsw.gov.au/belongings-home/about-belongings/belongings-guide/>. See also Fernandes: 'As this generation passes away and their belongings are being dumped, younger family members wish they knew more about Grandad or Mum and asked them questions whilst they were still alive. Why did Pop migrate here? What did Mama bring with her and why? What was life like for a "new Australian" in the 1950s? Too often this history is lost. Belongings helps to save some of this history.'

${ }^{20}$ Andrea Fernandes covers the history of the making of the exhibition in 'Belongings: Post-WW2 Migration Memories \& Journeys', which is available on the exhibition website. Jennifer Barrett and John Petersen give an overview of the history of MHC and examine Belongings in the context of debates in museum studies on the web as a 'museum without walls' for community use, see 'The Museum, Democracy and Domesticity: Who's in Whose Web?', paper delivered to the Museums Australia National Conference, Canberra, May 2007,

<http://museumsaustralia.org.au/userfiles/file/Conference\%20Papers/2007/2007_Petersen.pdf>. Janis Wilton reviews the online exhibition and analyses in depth some of the objects and stories as examples of oral histories, stressing the importance of material culture in the telling of life stories, 'Belongings: Oral History, Objects and an Online Exhibition', Public History Review, vol. 16, 2009, pp. 119. Francesca Veronesi and Bert Bongers explore the possibilities of digital technologies in creating an interactive, multisensorial narrative space and experience between audiences and the virtual objects in a mixed media project titled Belongings: A Multisensory Experience of Australian Migration Heritage, 'Touching and Being Touched: Embodied Experiences with Belongings Carried Through Memory and Time', a paper presented at the IADIS International Conference Interfaces and Human Computer Interaction, 2010, pp. 333-7.

21 Teresa Iannelli, 'Teresa Iannelli' Migration Memories', in Belongings, ed. Fernandes, interview by Carmel Pantano, Leeton Italian Heritage Group,

<http://www.migrationheritage.nsw.gov.au/exhibition/belongings/iannelli/>.

22 Fernandes.

23 Baldassar.

24 Daniel Miller 'Behind Closed Doors' in Home Possessions. Material Culture Behind Closed Doors, ed. Daniel Miller, Berg, Oxford and New York, 2001, pp. 1-19. 
${ }^{25}$ Alison Blunt and Robyn Dowling, Home, Routledge, London and New York, 2006. See in particular pp. 196-252.

${ }^{26}$ Michelle Barrett, 'The Memory of Objects: Eurasian Women (re)Creating Identity and Belonging in the Post-migratory Home', in Imagining Home: Migrants and the Search for a New Belonging, Diana Glenn, Éric Bouvet and Sonia Floriani, Wakefield Press, Kent Town, South Australia, pp. 102-21. 27 Rita Wilson, 'Cultural (re)Locations: Narratives by Contemporary Italian Australian Women', in Literary and Social Diasporas: An Italian Australian Perspective, eds Gaetano Rando and Gerry Turcotte Peter Lang, Brussels Belgium, 2007 pp. 147-8. Wilson here is quoting Gustavo Pérez Firmat, Life on the Hyphen: The Cuban American Way, University of Texas Press, Austin, 2012, pp. 6-10.

28 Sara Ahmed, Claudia Castañeda, Anne-Marie Fortier and Mimi Sheller (eds), Uprootings/Regroundings: Questions of Home and Migration, Berg, Oxford and New York, 2003, p. 8. ${ }^{29}$ Ahmed et al., p. 9. See also Ghassan Hage, 'At Home in the Entrails of the West: Multiculturalism, Ethnic Food and Migrant Home-building', in Home/World: Space, Community and Marginality in Sydney's West, eds Helen Grace, Ghassan Hage, Lesley Johnson, Julie Langsworth and Michael Symonds Pluto, Sydney, 1997; and Eva Hoffman, Lost in Translation: A Life in a New Language, Minerva, London, 1998.

${ }^{30}$ Ahmed, et al., pp. 1-2.

31 Ibid., p. 2.

32 Ibid., p. 4.

33 Ibid., p. 10.

34 Domenica Scarcella, 'Domenica Scarcella's Migration Memories', in Fernandes (ed.), Belongings, interview by Linda Nellor, Co.As.It,

<http://www.migrationheritage.nsw.gov.au/exhibition/belongings/scarcella/>.

35 Carmela Pasquetti, 'Carmela Pasquetti's Migration Memories', in Fernandes (ed.), Belongings, interview by Carmel Pantano, Leeton Italian Heritage Group,

<http://www.migrationheritage.nsw.gov.au/exhibition/belongings/pasquetti/>.

36 Pasquetti.

37 Joseph Sciorra, 'Listening with an Accent', in Italian Folk: Vernacular Culture in Italian-American Lives, ed. Joseph Sciorra, Fordham University Press, New York, 2011, p. 4.

38 Concetta Cosentino, 'Concetta Cosentino's Migrant Memories', in Fernandes (ed.), Belongings, interview by Linda Nellor Co.As.It., <http://www.migrationheritage.nsw.gov.au/exhibition/belongings/cosentino/>.

39 Raffaella Porcu, 'Raffaella Porcu's Migration Memories', in Fernandes (ed.), Belongings, interview by Carmel Pantano, Leeton Italian Heritage Group, <http://www.migrationheritage.nsw.gov.au/exhibition/belongings/porcu/>. ${ }^{40}$ Sciorra, p. 3. For a discussion of bella figura see Gloria Nardini, Che Bella Figura! The Power of Performance in an Italian Ladies' Club in Chicago, SUNY Press, Albany, 1999. 
41 Teresa Pirrottina, 'Teresa Pirrottina's Migration Memories', in Fernandes (ed.), Belongings, interview byAndrea Fernandes, NSW Migration Heritage Centre with the assistance of Carmel Pantano, Leeton Italian Heritage Group,

<http://www.migrationheritage.nsw.gov.au/exhibition/belongings/pirrottina/>.

42 Andrea Fernandes, personal communication with the author, 17 October 2012.

43 Writing with an Accent is the title of a book by Edvige Giunta on contemporary Italian American women writers. Giunta reclaims the concept of accent to signify the capacity to speak from multiple cultural perspectives: 'a perpetual sense of loss, of absence, but also a stubborn determination to liveculturally, linguistically, creatively—in both worlds'. Edvige Giunta, Writing with an Accent.

Contemporary Italian American Women Authors, Palgrave, New York, 2002, p. 3.

44 Baldassar and Gabaccia.

${ }^{45}$ A search of Belongings by cultural backgrounds reveals that 29 people of Italian background shared their stories for the project. Of the 78 objects narrated in the exhibition 47 (60 per cent) are objects of domestic use, such as tea and coffee cups, cooking equipment, linen, sawing and embroidering tools, trunks and ornaments. The high percentage of domestic objects might be explained by the labour division in the home, since 73 per cent of the project participants are women.

46 Teresa Restifa, 'Teresa Restifa's Migration Memories', in Belongings, ed. Fernandes, interview by Linda Nellor, Co.As.It, <http://www.migrationheritage.nsw.gov.au/exhibition/belongings/restifa/>. 47 Joseph Pugliese has written extensively on the politics of race and immigration policies in Australia. On Italian migration see specifically Joseph Pugliese, 'In the Ruins of Diaspora: A Southern Italian Perspective', in Issues in Travel Writing : Empire, Spectacle, and Displacement, eds Kristi Siegel, Peter Lang, New York, 2002, pp. 229-44; 'Race as Category Crisis: Whiteness and the Topical Assignation of Race', Social Semiotics, vol. 12, no. 2, 2002, pp. 149-68; and 'Diasporic Architecture: Whiteness and the Cultural Politics of Space', in Constellation of the Transnational: Modernity, Culture, Critique, ed. Sudeep Dasgupta Rodopi, Amsterdam, 2007, pp. 23-49. See also The Department of Immigration and Multicultural and Indigenous Affairs, Report of the Review of Settlement Services for Migrants and Humanitarian Entrants, The Department of Immigration and Multicultural and Indigenous Affairs, Canberra, 2003, pp. 24-5.

48 See for instance Andrew Jakubowicz's reconstruction of the Good Neighbour Movement: 'Commentary on Welcoming New Migrants as New Australians', Making Multicultural Australia, <http://www.multiculturalaustralia.edu.au/history/timeline/period/White-

Australia/screen/8.Welcoming-new-migrants-as-New-Australians->.

${ }^{49}$ Ernesto de Martino, 'Apocalissi Culturali e Apocalissi Psicopatologiche'; La Fine del Mondo; Furore. Simbolo. Valore; The Land of Remorse.

50 See Maldonato; see also Federico Leoni, 'Senso e Crisi. Fenomenologia della Cultura e Psicopatologia Fenomenologica in Ernesto De Martino e Bruno Callieri', in Dell'Apocalisse. Antropologia e 
Psicopatologia di Ernesto De Martino, eds Bruna Baldacconi and Pierangela di Lucchio, Alfredo Guida Editore, Napoli, 2005, pp. 133-52.

51 De Martino, 'Apocalissi Culturali', pp. 110-15.

52 The English translations of these texts are: Jean-Paul Sartre, Nausea, Hamish Hamilton, London, 1962; Alberto Moravia, Boredom, New York Review of Books Classics, New York, 2004; Hugo von Hoffmansthal, The Lord Chandos Letter, Marlboro Press, Vt. 1986; Marcel Proust, In Search of Lost Time, Modern Library, New York, 2003.

53 De Martino, 'Apocalissi Culturali', p. 103. See also De Martino, Furore and De Martino, La Fine del Mondo. All the translations from De Martino are mine.

54 De Martino, La Fine del Mondo, pp. 668-70 and p. 279: 'Historicism intends history as man as producer of cultural values, that is as an act of transcendence of the here and now of becoming'. 55 De Martino, 'Apocalissi Culturali', p. 103.

56 Ibid., pp. 126-7.

57 Franca Arena, 'Franca Arena's Migration Memories in Fernandes (ed.), Belongings, interview by Andrea Fernandes, NSW Migration Heritage Centre,

<http://www.migrationheritage.nsw.gov.au/exhibition/belongings/arena/>.

58 Pirrottina.

${ }^{59}$ Rosina Rombola, 'Rosina Rombola's Migration Memories', in Fernandes (ed.), Belongings, interview by Carmel Pantano, Leeton Italian Heritage Group,

<http://www.migrationheritage.nsw.gov.au/exhibition/belongings/rombola/>.

60 Edda Marcuzzi, 'Edda Marcuzzi's Migration Memories' Fernandes (ed.), Belongings, interview by Bridget Guthrie, Albury City,

<http://www.migrationheritage.nsw.gov.au/exhibition/belongings/marcuzzi/>.

61 De Martino, in the first half of the 1960 s - the same period as much Italian migration to Australiawrites about 'the problems of cultural homelands and their relationships' in connection with migration because 'we live in a period of migrations, of encounters and comparisons', La Fine del Mondo, p. 478. 62 De Martino, 'Apocalissi Culturali', pp. 130-1.

63 Ibid.

${ }^{64}$ Gina Bortolin-Papa, 'Gina Bortolin-Papa's Migration Memories', in Fernandes (ed.), Belongings, interview by Linda Nellor,

<http://www.migrationheritage.nsw.gov.au/exhibition/belongings/bortolin-papa/>.

65 Brett Neilson, 'On the Ambiguity of Ambidextrousness, or, What is an Innovative Action?',

CLCWeb: Comparative Literature and Culture, vol. 12, no. 4, 2010, p. 5.

<http://docs.lib.purdue.edu/clcweb/vol12/iss4/6>.

66 Paolo Virno, 'Antropologia e Teoria delle Istituzioni', Transversal, Progressive Institutions, no. 4, 2007, <http://eipcp.net/transversal/0407/virno/it>. 
${ }^{67}$ Italian psychoanalyst Claudio Neri has written about De Martino's notion of cultural apocalypse and migration, with special attention to the role of domestic objects: Claudio Neri, 'Il Calore Segreto Degli Oggetti: A Proposito di un Saggio di Ernesto De Martino', Quaderni di Psicoterapia Infantile, vol. 40, 1998, <www.claudioneri.it/pubblicazioni/139.pdf>.

68 Rombola.

${ }^{69}$ Silvia Saccaro, 'Silvia Saccaro's Migration Memories' in Fernandes (ed.), Belongings, interview by Sandy Minter, Lake Macquarie City Art Gallery,

<http://www.migrationheritage.nsw.gov.au/exhibition/belongings/saccaro/>.

${ }^{70}$ Silvana Toia, 'Silvana Toia's Migration Memories', in Fernandes (ed.), Belongings, interview by Linda Nellor, Co.As.It, <http://www.migrationheritage.nsw.gov.au/exhibition/belongings/toia/>.

71 Porcu.

72 De Martino, La Fine del Mondo, p. 473. 